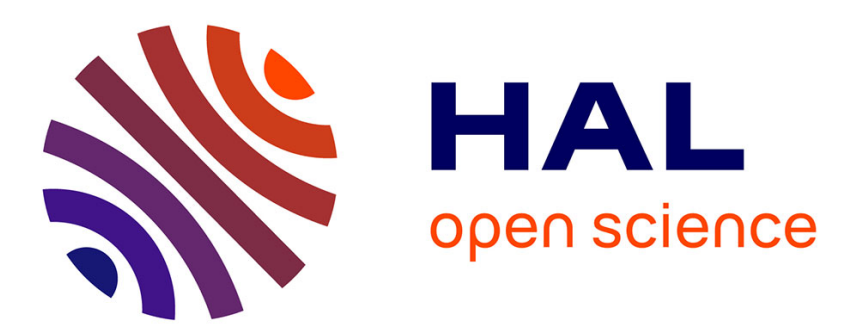

\title{
Kinetic studies and production rate of melatonin in pony mares
}

\author{
Daniel Guillaume, N. Rio, P.L. Toutain
}

\section{To cite this version:}

Daniel Guillaume, N. Rio, P.L. Toutain. Kinetic studies and production rate of melatonin in pony mares. AJP - Regulatory, Integrative and Comparative Physiology, 1995, 268, pp.R1236-R1241. hal02701727

\section{HAL Id: hal-02701727 \\ https://hal.inrae.fr/hal-02701727}

Submitted on 1 Jun 2020

HAL is a multi-disciplinary open access archive for the deposit and dissemination of scientific research documents, whether they are published or not. The documents may come from teaching and research institutions in France or abroad, or from public or private research centers.
L'archive ouverte pluridisciplinaire HAL, est destinée au dépôt et à la diffusion de documents scientifiques de niveau recherche, publiés ou non, émanant des établissements d'enseignement et de recherche français ou étrangers, des laboratoires publics ou privés. 


\title{
Kinetic studies and production rate of melatonin
}

\section{in pony mares}

\author{
D. GUILLAUME, N. RIO, AND P. L. TOUTAIN \\ Institut National de la Recherche Agronomique de Tours, Physiologie de la Reproduction \\ des Mammifères Domestiques, 37380 Nouzilly; and Ecole Nationale Vétérinaire de Toulouse, \\ Unité Associée Institut National de la Recherche Agronomique de Physiopathologie \\ et Toxicologie Expérimentales, 31076 Toulouse Cédex, France
}

Guillaume, D., N. Rio, and P. L. Toutain. Kinetic studies and production rate of melatonin in pony mares. $A m$. J. Physiol. 268 (Regulatory Integrative Comp. Physiol. 37): R1236-R1241, 1995.-The aims of the present study were to determine basic kinetic parameters and the nycthemeral production rate of melatonin in the horse. Seven pony mares were used for the kinetic studies. Five other pony mares were used under long and short days for the production rate studies. Melatonin was administered by intravenous, oral, and intragastric routes at different dose levels. The plasma melatonin clearance was $1.02 \pm 0.31 \mathrm{l} \cdot \mathrm{kg}^{-1} \cdot \mathrm{h}^{-1}$, and the volume of distribution was $0.89 \pm 0.53 \mathrm{l} / \mathrm{kg}$ for the $0.4 \mu \mathrm{g} / \mathrm{kg}$ melatonin dose. The systemic availability after oral and intragastric administration was consistently low $(\leq 10 \%)$. The hourly melatonin production rates during short $(36 \pm 33.6$ $\left.\mathrm{ng} \cdot \mathrm{kg}^{-1} \cdot \mathrm{h}^{-1}\right)$ and long nights $\left(42 \pm 24.0 \mathrm{ng} \cdot \mathrm{kg}^{-1} \cdot \mathrm{h}^{-1}\right)$ were not significantly different. It is concluded that the oral dose of exogenous melatonin required to control reproductive pattern in horses would need to be 10 times higher than the nocturnal melatonin production $(0.5 \mu \mathrm{g} / \mathrm{kg})$ to obtain a physiological plasma melatonin concentration.

horse; clearance; systemic availability; nocturnal production rate

MELATONIN IS INVOLVED in the determination of the photoperiod and participates in the control of the animal's reproductive cycle both in short-day breeders, such as the ewe (17), and in long-day breeders, such as the mare $(8,11,22,23)$. A photoperiodic treatment with a 14.5:9.5-h light-dark cycle was shown to advance the first ovulation in mares following the winter inactivity (18).

It has also been demonstrated in different species, including the horse, that an administration of exogenous melatonin can be used directly to modulate a photoperiodic treatment and that a $12 \mathrm{mg}$ melatonin dose, $4 \mathrm{~h}$ before a stimulating short night, delays the first ovulation in the mare (9).

The rational pharmacological use of melatonin to control reproductive cycles is based on the selection of an appropriate schedule for the time of melatonin administration and an appropriate dosage regimen (dose, interval of administration, and route of administration); the former aspect has been partially documented (10).

The present experiment was designed to determine the basic pharmacokinetic parameters of melatonin, its oral bioavailability, and an effective melatonin dosage regimen in the horse. The physiological melatonin production rate was also determined to assess the physiological meaning of the melatonin-tested doses.

\section{MATERIALS AND METHODS}

Animals. Seven Welsh pony mares $(298 \pm 49 \mathrm{~kg}), 14.4 \pm 3$ yr old, from the experimental herd at Institut National de la Recherche Agronomique, Nouzilly, were used in the first experiment (melatonin pharmacokinetics). Five pony mares $(239 \pm 60 \mathrm{~kg}), 7.2 \pm 3 \mathrm{yr}$ old, were used in the second experiment (melatonin production-rate determination). Horses were given two equal feedings per day, at 0800 and 1600 , that included oats, corn, and lucerne. The morning meal was suppressed, and the afternoon meal was given after the last blood sample on the sampling day.

Photoperiodic treatment. The experiments were carried out at Nouzilly, France, $45^{\circ} \mathrm{N}$. The photoperiodic treatment in all mares started at the end of December. Mares in the pharmacokinetic experiment were maintained under long days (14.5: 9.5-h light-dark). Those in the production-rate experiment were kept under short days (in lightproof boxes) (10.5:13.5-h light-dark) until the first blood sampling session at the end of April. They were then maintained under long days (14.5:9.5-h light-dark), the second blood sampling session being carried out 1 mo later.

Melatonin administration and blood sampling. Crystalline melatonin (Sigma Chemical, St. Louis, MO) was used. Purity ( $>98 \%$ ) was checked by thin-layer chromatography. Melatonin was administered by intravenous, oral, and intragastric routes. The order of administration was randomized according to a Latin square with seven periods. An interval of at least 1 wk was allowed to elapse between each period.

For the two intravenous administrations, melatonin was dissolved in an appropriate volume of absolute ethanol (Prolabo, Normapur, Paris, France), so that a volume of $\sim 5 \mathrm{ml}$ could be administered.

For the oral administration trials, an appropriate volume of alcoholic solution, based on individual mare body weight, was spread on a sugar lump $(\sim 7 \mathrm{~g})$. The sugar lumps were left at room temperature to evaporate the ethanol, then stored at $-20^{\circ} \mathrm{C}$ until administration. The stability of melatonin at this temperature was demonstrated (9).

The melatonin solution was administered in the left jugular vein with a sterilized Teflon trocart (Intraflon, Vigon, Paris, France). Two doses (40 and $0.40 \mu \mathrm{g} / \mathrm{kg}$ iv) were administered in the pharmacokinetic experiment. Blood samples were collected from the right jugular vein in heparinized tubes (sodium heparinate) with a sterilized Teflon trocart. Blood samples were obtained before $(-20 \mathrm{~min},-10$, and $0 \mathrm{~min})$ and after ( 1 , $2,4,6,8,10,12,16,20,25,30,35,40,45,60,75,90,120,150$, $180,210,240,300,360,420,480,540$, and $660 \mathrm{~min}$ ) intravenous melatonin administration.

Melatonin was administered orally on a piece of sugar, as the horse had been trained to accept sugar spontaneously. The four dose levels $(40,4.0$, and 0.4 or $0.08 \mu \mathrm{g} / \mathrm{kg}$ ) were administered to each mare in the morning at 8 A.M., after switching on the light. For the intragastric administration trial, a $40 \mu \mathrm{g} / \mathrm{kg}$ dose in alcoholic solution $(5 \mathrm{ml})$ was administered to each mare with a Teflon catheter of appropriate length introduced into 
the nasostomach tube. A twitch was used to keep the horse under control during administration. Blood samples were obtained as with intravenous administration and according to the same schedule.

For the production-rate experiment, two series of jugular blood samples (corresponding to short and long days, respectively) were collected over $24 \mathrm{~h}$. Blood samples were obtained every $6 \mathrm{~min}, 18 \mathrm{~min}$ before switching off the light until $18 \mathrm{~min}$ after completion of the dark phase and hourly during the rest of the session. A cover was placed over the eyes of the mares, and a dim red light was used during the dark-phase blood collection.

For this second experiment, a single dose $(0.8 \mu \mathrm{g} / \mathrm{kg}$ iv $)$ was administered 2 mo after the second blood-sampling session to determine the individual plasma melatonin clearance in pony mares. Blood samples were taken as in the pharmacokinetic experiment. Blood was immediately centrifuged, and the plasma was frozen at $-20^{\circ} \mathrm{C}$ until assayed.

Melatonin assays. The melatonin plasma concentration was measured by adapting a specific radioimmunoassay technique previously described in sheep. The cross-reaction with related compounds was $<1 \%$ for $N$-acetylserotonin and 6 -hydroxymelatonin and totally absent for other compounds tested (24).

The assay was direct with ${ }^{125}$ I-labeled melatonin. Precipitation of the bound fraction was obtained with ovine serum raised against rabbit $\gamma$-globulin. It was adapted to the horse plasma by preparing a standard curve $(5-2,000 \mathrm{pg} / \mathrm{ml})$ in low-melatonin equine plasma. The melatonin in this lowmelatonin plasma was as low as the plasma in which the melatonin had been removed by charcoal treatment. The concentrations were calculated by two logit $\left(B / B_{0}\right)$ vs. $\log$ (dose) regressions; the first from 5 to $500 \mathrm{pg} / \mathrm{ml}$ and the second from 500 to $2,000 \mathrm{pg} / \mathrm{ml}$. All plasma samples from each horse were assayed at the same time. The pharmacokinetic and production rate trials were determined in two different series. The level of quantification was $5 \mathrm{pg} / \mathrm{ml}$, and the intra-assay coefficients of variation were $<10 \%$ at the level of quantification $(5 \mathrm{pg} / \mathrm{ml})$ and $<5 \%$ for physiological melatonin concentration $(40-60 \mathrm{pg} / \mathrm{ml})$. The interassay coefficient of variation was $<13 \%$.

Pharmacokinetic analysis. The pharmacokinetics of the melatonin plasma concentrations were analyzed using a program for nonlinear regression analysis adapted from MULTI analysis program (28).

Plasma melatonin concentrations obtained after intravenous melatonin administration were fitted to thr general polyexponential equation $(E q .1)$

$$
\mathrm{C}(t)=\sum_{i=1}^{n} Y_{i} \exp (-\lambda i t)
$$

In $E q .1, \mathrm{C}(t)$ is the melatonin plasma concentration $(\mathrm{pg} / \mathrm{ml})$ at time $t(\mathrm{~min}), Y_{i}(\mathrm{pg} / \mathrm{ml})$ is the coefficient of the exponential term, and $\lambda i\left(\mathrm{~min}^{-1}\right)$ is the exponential term; initial estimates were obtained using the residuals method (7). The data points were weighted by the inverse of the squared-fitted value (1/ $\left.\widehat{Y_{i}^{2}}\right)$.

The best fit was obtained by minimizing the weighted least-squares criteria, and the number of exponents $(1,2$, or 3$)$ needed for each data set was determined by application of the Akaike's information criterion (26). Based on this criterion, a triexponential equation was selected for the intravenous administration $(E q .2)$

$$
\mathrm{C}(t)=Y_{1} \exp \left(-\lambda_{1} t\right)+Y_{2} \exp \left(-\lambda_{2} t\right)+Y_{3} \exp \left(-\lambda_{3} t\right)
$$

In $E q .2, \mathrm{C}(t)$ is the melatonin concentration at time $t ; Y_{1}, Y_{2}$, and $Y_{3}(\mathrm{pg} / \mathrm{ml})$ are coefficients; and $\lambda_{1}, \lambda_{2}$, and $\lambda_{3}\left(\mathrm{~min}^{-1}\right)$ are exponents. Data were therefore analyzed using a threecompartment open model with melatonin elimination from the central compartment.

The estimated parameters $\left(Y_{1}, Y_{2}, Y_{3}\right.$, and $\left.\lambda_{1}, \lambda_{2}, \lambda_{3}\right)$ were used to solve the first-order rate constants of transfer from central to peripheral compartments $\left(K_{12}, K_{13}, K_{21}, K_{31}\right)$ using classical equations (7).

The volume of the central compartment was obtained with Eq. 3

$$
\mathrm{V}_{\mathrm{c}}=\operatorname{dose} /\left(Y_{1}+Y_{2}+Y_{3}\right)
$$

with dose, the administered dose $(0.4$ or $40 \mu \mathrm{g} / \mathrm{kg})$, and $Y_{1}, Y_{2}$, and $Y_{3}$, as previously defined.

The melatonin steady-state volume of distribution $\left(\mathrm{V}_{\mathrm{ss}}\right)$ was obtained using $E q .4$

$$
\mathrm{V}_{\mathrm{ss}}=\mathrm{V}_{\mathrm{c}}\left(1+K_{12} / K_{21}+K_{13} / K_{31}\right)
$$

with $V_{c}$, the volume of the central compartment, as given in $E q .3$, and $K_{12}, K_{13}, K_{21}$, and $K_{31}$, the first-order rate constants transfer between central and peripheral compartments.

The plasma melatonin clearance $(\mathrm{CL})$ was calculated using Eq. 5

$$
\mathrm{CL}=\text { dose } / \mathrm{AUC}
$$

In $E q .5$, AUC is the area under the plasma melatonin curve obtained by the trapezoidal method without extrapolation to infinity.

The terminal half-life $\left(t_{1 / 2}\right)$ was obtained using $E q .6$

$$
t_{1 / 2}=\ln (2) / \lambda_{3}
$$

with $\lambda_{3}$ as the slope of the terminal phase.

The mean residence time (MRT) of melatonin in the system, i.e., the mean time taken for a melatonin molecule to transit through the body, was calculated by the trapezoidal method without extrapolation to infinity (27).

Individual plasma melatonin concentrations obtained after oral and intragastric melatonin administrations were best fitted (Akaike's information criterion) using $E q .7$

$$
\begin{aligned}
\mathrm{C}(t)= & \left(Y_{1}+Y_{2}\right) \exp \left(-K_{\mathrm{a}} t\right) \\
& +Y_{1} \exp \left(-\lambda_{1} t\right)+Y_{2} \exp \left(-\lambda_{2} t\right)
\end{aligned}
$$

In $E q .7, \mathrm{C}(t)$ is the plasma melatonin concentration $(\mathrm{pg} / \mathrm{ml})$ at time $t$ (in $\mathrm{min}$ ); $Y_{\mathrm{I}}$ and $Y_{2}(\mathrm{pg} / \mathrm{ml})$, the pre-exponential coefficients; $\lambda_{1}$ and $\lambda_{2}\left(\mathrm{~min}^{-1}\right)$, the exponents corresponding to the distribution and elimination processes; and $K_{\mathrm{a}}\left(\mathrm{min}^{-1}\right)$, the first-order rate constant of absorption. The data were therefore described by a two-compartment model with a single process of absorption.

The plasma half-life $\left(t_{1 / 2}\right)$ was calculated using $E q .8$

$$
t_{1 / 2}=\ln (2) / \lambda_{2}
$$

with $\lambda_{2}$ the slope of the terminal phase.

$T_{\max }$, the time corresponding to the occurrence of the maximal plasma concentration $\left(\mathrm{C}_{\max }\right)$, was calculated from $E q$. 7. The systemic availabilities (F\%) of melatonin after the oral and intragastric administrations were calculated using $E q .9$

$$
\mathrm{F} \%=\frac{\mathrm{AUC}_{(\mathrm{PO} \text { or IG) }} \times \text { dose }_{(\mathrm{IV})}}{\mathrm{AUC}_{(\mathrm{IV})} \times \operatorname{dose}_{(\mathrm{PO} \text { or IG })}} \times 100
$$

with AUC, the area under the curve after oral (PO), intragastric (IG), and intravenous (IV) administration. The $0.40 \mu \mathrm{g} / \mathrm{kg}$ IV dose was used to calculate the absolute bioavailability. 
The mean absorption times (MAT) after PO and IG administration were calculated using $E q .10$

$$
\mathrm{MAT}_{\text {(PO or IG) }}=\mathrm{MRT}_{\text {(PO or IG) }}-\mathrm{MRT}_{\text {(IV) }}
$$

with $\mathrm{MRT}_{(\mathrm{N})}$, the MRT calculated after the $0.40 \mu \mathrm{g} / \mathrm{kg}$ iv dose, and $\mathrm{MRT}_{(\mathrm{PO} \text { or IG), }}$, the MRT calculated after oral or intragastric administration, respectively.

Melatonin production rate. The daily production rate (PR) of melatonin was calculated using $E q .11$

$$
\mathrm{PR}=\mathrm{AUC}_{(0-t)} \times \mathrm{CL}
$$

In $E q .11, \mathrm{AUC}_{(\mathrm{o}-t)}$ is the area under the plasma melatonin curve for the night duration $(9.5$ or $13.5 \mathrm{~h}$ ) and was calculated by linear trapezoidal rule; $\mathrm{CL}_{\mathrm{L}}$ is the individual plasma clearance calculated after a dose of $0.80 \mu \mathrm{g} / \mathrm{kg}$ iv of melatonin (see Eq. 5).

Statistical analysis. Statistical analysis was performed using STATGRAPHICS (STSC, Rockville, MD). Values are reported as means \pm SD. For the intravenous studies, parameter comparisons between doses were based on an analysis of variance (ANOVA) with doses and horses as the main factors, followed by the Bonferroni test for comparison between the means. Homogeneity of variance was tested using the Bartlett's test. Nonparametric analysis of variances (Friedman two-way analysis) was carried out when the variances were not homogeneous.

For the oral studies, ANOVA, with doses and horses as main factors, were carried out using the same procedure as for the intravenous studies. Differences were considered as significant for $P<0.05$.

\section{RESULTS}

Plasma melatonin kinetics. Results are only available for six horses, because of difficulties encountered with one of the horses. The semilogarithmic plots of melatonin plasma concentrations ( $\mathrm{pg} / \mathrm{ml}$ ) vs. time (in min) after the intravenous administration (40 and $0.40 \mu \mathrm{g}$ / $\mathrm{kg}$ ) are shown in Fig. 1 for a representative horse.

The plasma clearance calculated after the $40 \mu \mathrm{g} / \mathrm{kg}$ melatonin dose $\left(1.83 \pm 0.39 \mathrm{l} \cdot \mathrm{kg}^{-1} \cdot \mathrm{h}^{-1}\right)$ was significantly higher than after the $0.40 \mu \mathrm{g} / \mathrm{kg}$ dose $(1.02 \pm 0.31$ $1 \cdot \mathrm{kg}^{-1} \cdot \mathrm{h}^{-1}$ ) (Bonferroni test, $P<0.01$ ). The mean steady-state volume of distribution was higher $(2.11 \pm 1.75 \mathrm{l} / \mathrm{kg})$ for the $40 \mu \mathrm{g} / \mathrm{kg}$ dose than for the $0.40 \mu \mathrm{g} / \mathrm{kg}$ dose $(0.89 \pm 0.53 \mathrm{l} / \mathrm{kg})$, but the difference was not statistically significant (Friedman analysis,

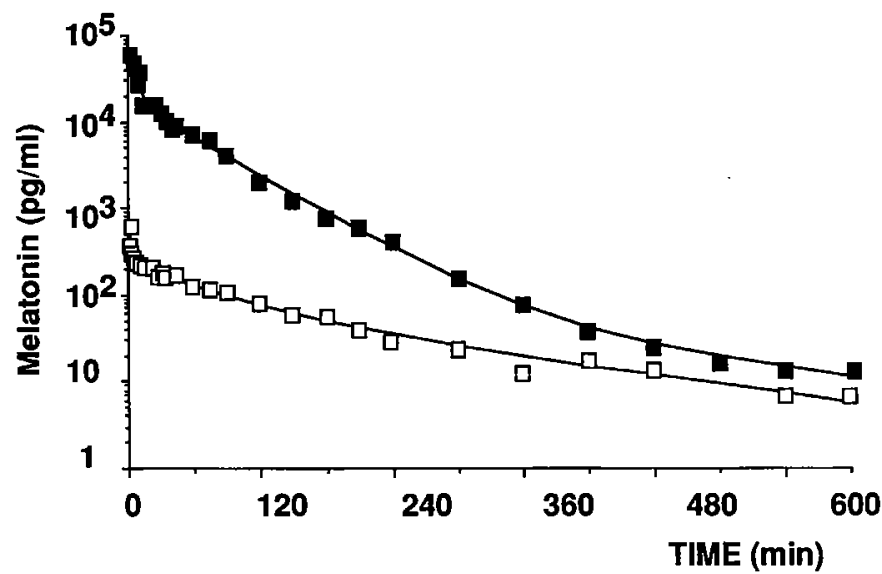

Fig. 1. Semilogarithmic plot of observed plasma melatonin concentration after an intravenous administration of melatonin at a dose of 40 (घ) or $0.4 \mu \mathrm{g} / \mathrm{kg}(\square)$ to a representative horse.
$P>0.05)$; finally, MRTs, which depend on both clearance and volume of distribution, did not differ significantly between the two doses $(68 \pm 53$ and $58 \pm 46 \mathrm{~min}$ for the high- and low-melatonin doses, respectively; ANOVA, $P>0.05$ ). Other parameters are given in Table 1.

The semilogarithmic plots of melatonin plasma concentrations vs. time (in $\mathrm{min}$ ) for the oral administrations $(40,4.0$, and $0.4 \mu \mathrm{g} / \mathrm{kg}$ ) are shown in Fig. 2 for a representative horse. The plasma melatonin concentration after oral administration of $0.08 \mu \mathrm{g} / \mathrm{kg}$ was undetectable. The plasma melatonin concentration increased rapidly after administration of the three tested oral doses, to reach a maximum value $\left(T_{\max }\right)$ after $\sim 30 \mathrm{~min}$. There was no statistical difference between doses for $T_{\max }$ (ANOVA, $P>0.05$ ); in contrast, the maximum plasma melatonin concentration was proportional to the administered dose, suggesting linearity of melatonin absorption (Table 2$)$. The terminal half-lives ( $\sim 100$ $110 \mathrm{~min}$ ) were similar for the three dosage levels and those of the intravenous studies (108-138 min) (ANOVA, $P>0.05$ ), suggesting that melatonin absorption occured more rapidly than melatonin elimination. The MAT, i.e., the mean time taken for a melatonin molecule to be absorbed, was $50 \pm 15(40 \mu \mathrm{g} / \mathrm{kg}$ dose $)$ and $33 \pm 17$ $\min (4.0 \mu \mathrm{g} / \mathrm{kg}$ dose $)$. The MAT for the lowest dose could only be calculated in two horses and is not reported. The mean systemic availability (for all oral dose levels) was low $(\sim 8-12 \%)$ with no significant difference between dosage rates (ANOVA, $P>0.05$ ). Mean parameters are given in Table 2 for the three oral doses tested. The plasma melatonin concentration was immediately increased after an intragastric melatonin administration (40 $\mu \mathrm{g} / \mathrm{kg})$, and maximal plasma values were observed at the first sampling time (1-min postadministration) in four of the six horses (see DISCUSSION). The bioavailability was significantly lower $(4.1 \pm 2.4 \%)$ after the intragastric administration than after oral administration of the same dose $(8.8 \pm 3.3 \%)$ (paired $t$-test, $P<0.05)$.

Melatonin production rate. The melatonin kinetic parameters for the five horses used to evaluate melatonin production rate are given in Table 1 . The plasma clearance $\left(1.30 \pm 0.28 \mathrm{l} \cdot \mathrm{kg}^{-1} \cdot \mathrm{h}^{-1}\right)$ was not significantly different from the clearance calculated with the 0.4 $\mu \mathrm{g} / \mathrm{kg}$ dose $\left(1.02 \pm 0.31 \mathrm{l} \cdot \mathrm{kg}^{-1} \cdot \mathrm{h}^{-1}\right)$. None of the other parameters $\left(\mathrm{V}_{\mathrm{ss}}, \mathrm{V}_{\mathrm{c}}, \mathrm{MRT}\right.$, and half-life) was significantly different from those calculated for the $0.4 \mu \mathrm{g} / \mathrm{kg}$ dose administered to the six other horses ( $t$-test, $P>0.05$ ).

The secretion pattern of a representative mare is given in Fig. 3. Total melatonin production rate was higher during a long night of $13.5 \mathrm{~h}(569 \pm 325 \mathrm{ng} / \mathrm{kg})$ than during a short night of $9.5 \mathrm{~h}(343 \pm 317 \mathrm{ng} / \mathrm{kg})$ (paired $t$-test, $P<0.1$ ), but the hourly melatonin production rates $\left(36 \pm 33.6\right.$ and $\left.42 \pm 24.0 \mathrm{ng} \cdot \mathrm{kg}^{-1} \cdot \mathrm{h}^{-1}\right)$ did not differ significantly between the two types of night (paired $t$-test, $P>0.05$ ).

\section{DISCUSSION}

The rational use of melatonin to control reproductive patterns in mares requires, for a given route of administration, determination of the appropriate dosage regi- 
Table 1. Pharmacokinetic parameters of melatonin after an intravenous bolus administration of melatonin at different dose levels in two groups of pony mares

\begin{tabular}{|c|c|c|c|c|}
\hline \multirow[t]{2}{*}{ Parameters } & \multicolumn{2}{|c|}{$\begin{array}{c}\text { Pharmacokinetic Trial, } \\
\mu \mathrm{g} / \mathrm{kg}(n=6)\end{array}$} & \multirow{2}{*}{$\begin{array}{l}\text { Statistical } \\
\text { Significance } \\
\text { of Dose }\end{array}$} & \multirow{2}{*}{$\begin{array}{c}\text { Production- } \\
\text { Rate Trial, } \\
0.8 \mu \mathrm{g} / \mathrm{kg} \\
(n=5)\end{array}$} \\
\hline & 40 & 0.4 & & \\
\hline Clearance, $\mathrm{l} \cdot \mathrm{kg}^{-1} \cdot \mathrm{h}^{-1}$ & $1.83 \pm 0.39$ & $1.02 \pm 0.31$ & $P<0.01$ & $1.30 \pm 0.28$ \\
\hline $\mathrm{V}_{\mathrm{c}}, \mathrm{l} / \mathrm{kg}$ & $1.04 \pm 0.80$ & $0.35 \pm 0.15$ & NS & $0.43 \pm 0.10$ \\
\hline $\mathrm{V}_{\mathrm{ss}}, \mathrm{l} / \mathrm{kg}$ & $2.11 \pm 1.75$ & $0.89 \pm 0.53$ & NS & $1.92 \pm 0.23$ \\
\hline Half-life, in min & $138(99-178)$ & $108(51-170)$ & NS & $109(47-282)$ \\
\hline MRT, in $\min$ & $68 \pm 53$ & $58 \pm 46$ & NS & $42 \pm 3.8$ \\
\hline $\mathrm{AUC}, \mu \mathrm{g} \cdot \min \cdot \mathrm{mil}^{-1}$ & $1,370 \pm 330$ & $24.9 \pm 0.61$ & $\mathrm{NC}$ & $38.4 \pm 0.97$ \\
\hline
\end{tabular}

Values are means $\pm S D$; values in parentheses are ranges. $V_{c}$, initial volume of distribution; $V_{s s}$, steady-state volume of distribution; MRT, mean residence time; and AUC, area under curve. Clearance, MRT, and AUC were calculated by the trapezoidal rule without extrapolation to infinity; $\mathrm{V}_{\mathrm{c}}$ and $\mathrm{V}_{\mathrm{ss}}$ were calculated using compartmental modeling; NS, not significant; NC, not calculated. Pharmacokinetic data were subjected to statistical analysis using an analysis of variance (ANOVA) with two factors (horse, dose). Comparison by $t$-test showed that there was no significant difference between the $0.4 \mu \mathrm{g} / \mathrm{kg}$ dose (pharmacokinetic trial) and the $0.8 \mu \mathrm{g} / \mathrm{kg}$ dose (production-rate trial).

men. In the horse, the oral route is most convenient when long-term treatment is in order, especially if mimicking the natural endogenous rhythm is a prerequisite to melatonin efficacy, as has been shown in the gilt to overcome delayed puberty (20). Because of the particularity of the digestive physiology in horses, however, oral-route efficiency, in terms of systemic bioavailability, may vary considerably depending on the drug tested. Pharmacokinetics are generally used to establish the optimal dosage regimen when a therapeutic drug level has been determined. Effective plasma melatonin levels can be assumed, as a result of experiments with photoperiod, to be equal to the physiological melatonin levels observed during the night. In other words, the systemically available fraction of melatonin following an exogenous administration must be of the same order of magnitude as the spontaneous melatonin production rate. Our experiment was therefore designed to document both oral-route performance and the physiological production rate of melatonin in horses.

Clearance is a basic pharmacokinetic parameter, which expresses the body's capacity to eliminate and/or metabolize a drug. In the present experiment, the estimated plasma clearance in five horses (production-rate studies) was $1.31 \cdot \mathrm{kg}^{-1} \cdot \mathrm{h}^{-1}$, which is very similar to that found

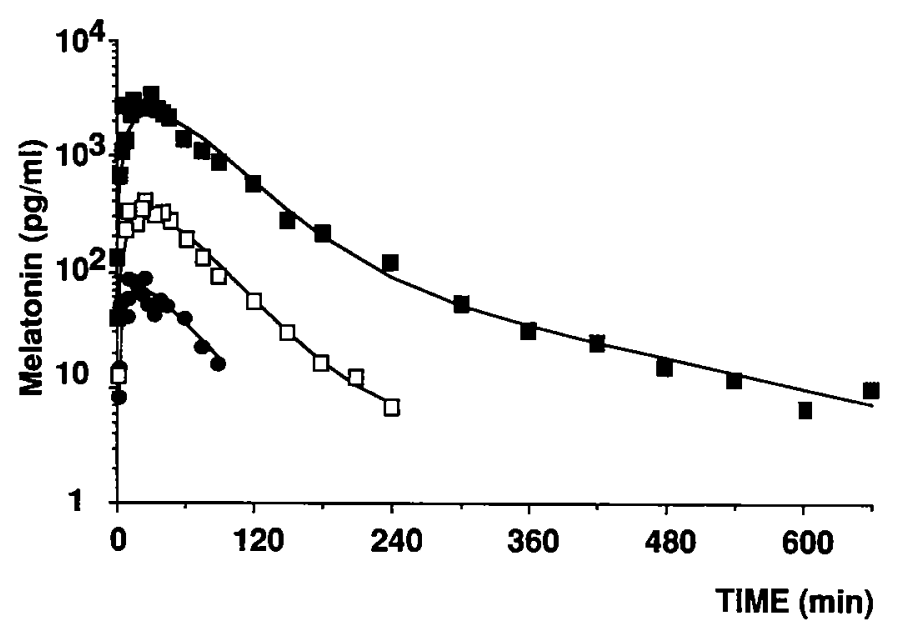

Fig. 2. Semilogarithmic plot of plasma melatonin concentration after an oral administration of melatonin at a dose of $40(\square), 4(\square)$ or 0.4 $\mu \mathrm{g} / \mathrm{kg}(\mathbf{o})$. in cows $\left(1.44 \mathrm{l} \cdot \mathrm{kg}^{-1} \cdot \mathrm{h}^{-1}\right)$ (2). This value is also similar to the hepatic plasma flow in horses (4). As the main pathway for melatonin metabolism in humans and rodents is hepatic $(12,13)$, the calculated clearance value in the horse suggests the existence of a first-pass hepatic effect for melatonin, as reported by others (19). One consequence of the first-pass hepatic effect is that the oral bioavailability of melatonin should be $<100 \%$ (see below).

Kinetic parameters were obtained during the day in the present experiment. Mid-dark melatonin clearance was reported to be higher than midlight clearance in rats (15). However, as a circadian rhythm of melatonin clearance has not been reported in humans (15), cows (3), or sheep, (5) we assumed that the calculated clearance obtained during the light phase was identical to that obtained during the night for the production-rate calculation.

Melatonin clearance was shown to be dose dependent in the six other horses, the clearance obtained with the highest doses being higher than that obtained with the lowest dose $\left(1.83\right.$ compared with $1.021 \cdot \mathrm{kg}^{-1} \cdot \mathrm{h}^{-1}$ for the 40 and $0.4 \mu \mathrm{g} / \mathrm{kg}$ doses, respectively). Similarly, the steady-state volume of distribution was higher (2.11 vs. $0.89 \mathrm{l} / \mathrm{kg}$ ) with the highest melatonin dose. These results were rather unexpected, as melatonin kinetics were reported to be linear (dose independent) in other species, including sheep (5), humans (15), and rats (6). The clearance values obtained in the present experiment with the lowest tested doses $(0.40 \mu \mathrm{g} / \mathrm{kg}$ with 6 horses and $0.8 \mu \mathrm{g} / \mathrm{kg}$ with 5 other horses) were not significantly different and can be considered as physiological, as they were obtained with melatonin doses of the same order of magnitude as the physiological production rate of melatonin (see below). In contrast, the $40 \mu \mathrm{g} / \mathrm{kg}$ melatonin dose gave much higher than physiological plasma concentrations of melatonin and led to some nonlinearity in melatonin disposition (increasing the volume of distribution, metabolism, and/or elimination). This point must be taken into account when production rates or absolute bioavailability of melatonin are measured in horses, and we suggest that the reference intravenous administration should be $<1 \mu \mathrm{g} / \mathrm{kg}$. It should be noted that the plasma half-life (108-138 $\mathrm{min}$ ) was not affected by the tested doses. This is because plasma half-life is a hybrid 
Table 2. Pharmacokinetic parameters of melatonin after oral administration of melatonin at three different dose levels and a nasogastric administration in six pony mares

\begin{tabular}{|c|c|c|c|c|c|}
\hline \multirow{2}{*}{ Parameters } & \multicolumn{3}{|c|}{$\begin{array}{c}\text { Oral Administration, } \\
\qquad \mu \mathrm{g} / \mathrm{kg}\end{array}$} & \multirow{2}{*}{$\begin{array}{l}\text { Statistical } \\
\text { Significance } \\
\text { of Dose }\end{array}$} & \multirow{2}{*}{$\begin{array}{c}\text { Intragastric } \\
\text { Administration, } \\
40 \mu \mathrm{g} / \mathrm{kg}\end{array}$} \\
\hline & 40 & 4 & 0.4 & & \\
\hline Half-life, in $\min$ & $105(68-149)$ & $101(51-199)$ & $108(30-309)$ & NS & $\mathrm{NC}$ \\
\hline MRT, in $\min$ & $89 \pm 16$ & $71 \pm 13$ & $53 \pm 23$ & $P<0.01$ & $89 \pm 20$ \\
\hline MAT, in $\min$ & $50 \pm 15$ & $33 \pm 17$ & $\mathrm{NC}$ & $\mathrm{NC}$ & $47 \pm 23$ \\
\hline $\mathrm{C}_{\max }, \mathrm{pg} / \mathrm{ml}$ & $2,886 \pm 1,706$ & $283 \pm 118$ & $47 \pm 23$ & $\mathrm{NC}$ & $1,137 \pm 710$ \\
\hline $\mathrm{T}_{\max }$, in $\min$ & $31 \pm 7$ & $32 \pm 11$ & $23 \pm 13$ & NS & $30 \pm 1.73$ \\
\hline $\mathrm{AUC}, \mu \mathrm{g} \cdot \min \cdot \mathrm{ml}^{-1}$ & $282 \pm 138$ & $26 \pm 12$ & $3.71 \pm 3.12$ & $\mathrm{NC}$ & $119 \pm 78$ \\
\hline $\mathrm{F} \%$ & $8.8 \pm 3.3$ & $9.8 \pm 4.8$ & $12.0 \pm 4.6$ & NS & $4.1 \pm 2.4$ \\
\hline
\end{tabular}

Values are means $\pm \mathrm{SD}$; values in parentheses are ranges. MAT, mean absorption time; $\mathrm{C}_{\max }$, maximal plasma concentration; $\mathrm{T}_{\max }$, time of peak plasma concentration; and F\%, systemic availability in percent. MRT, MAT, and AUC were calculated by trapezoidal rule without extrapolation to infinity; NS, not significant; NC, not calculated. Oral route data were subjected to statistical analysis using an ANOVA with two factors (horse, dose). Comparison of oral and intragastric administration of $40 \mu \mathrm{g} / \mathrm{kg}$ by a paired $t$-test revealed a significant difference between bioavailabilities $(P<0.05)$.

parameter, proportional to the volume of distribution and inversely proportional to clearance (7). It should also be noted that the volume of distribution $\left(\mathrm{V}_{\mathrm{ss}}\right)$ was relatively large $(\sim 1 \mathrm{l} / \mathrm{kg})$, suggesting an intracellular penetration of melatonin; this is consistent with the lipophilicity of the molecule and its ability to penetrate the cell and act directly on cell physiology, probably via calmodulin (1).
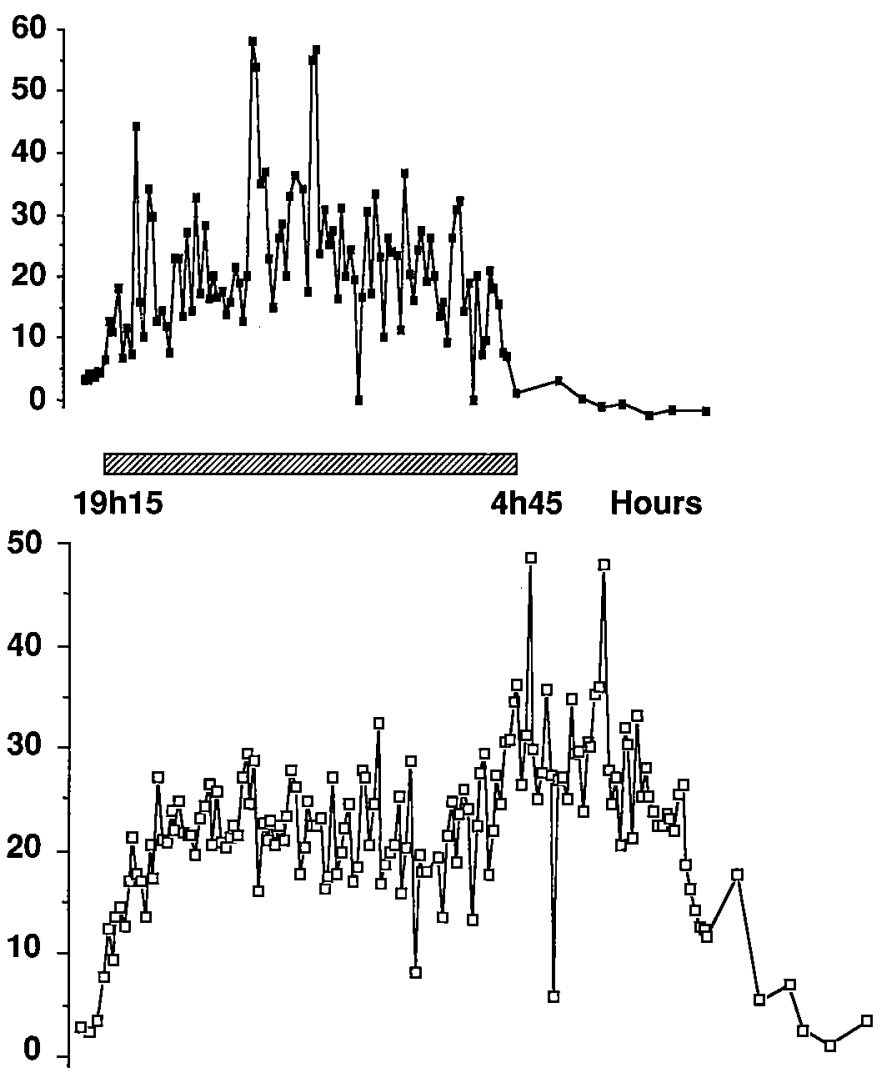

17 h45

7h15 Hours

Fig. 3. Plasma profile of melatonin concentration during a short (a) or a long ( $\square$ ) night in a representative horse. The dark phase (9.5 or $13.5 \mathrm{~h}$ ) is represented by the hatched bars.
The melatonin production rate in horses was $\sim 0.6$ $0.7 \mathrm{ng} \cdot \mathrm{kg}^{-1} \cdot \mathrm{min}^{-1}$, i.e., a total production of $343-569$ $\mathrm{ng} / \mathrm{kg}$ for night durations of 9.5 and $13.5 \mathrm{~h}$, respectively. These values are similar to those reported in cows (2) and humans (13), and pharmacological control of the reproductive pattern using melatonin in mares can be expected to require a systemic available melatonin dose of this order of magnitude. The instantaneous melatonin production rates during short and a long nights (9.5 and $13.5 \mathrm{~h}$, respectively) were also similar, so the total production rate was directly proportional to the night duration; this is at variance with observations in the Syrian hamster, in which the melatonin production rate increased sharply at the end of the night (21).

Calculation of a suitable dosage regimen of melatonin for use in horse should therefore be based only on the required pharmacological night duration and an appropriate route of administration able to provide a constant melatonin delivery.

The present experiment clearly demonstrates that, when melatonin is administered orally, the dosage level bioavailability factor must be adjusted to the bioavailability. The absolute bioavailability for all three tested doses $(40,4.0$, and $0.4 \mu \mathrm{g} / \mathrm{kg})$ was $<10 \%$. Such low availability is probably a consequence of both a first-pass hepatic effect and incomplete absorption as in humans, in whom the systemic availability was also reported to be $<10 \%$ (13). The absolute bioavailability was similar for all three doses, suggesting the linearity of melatonin absorption. A dose of $\sim 5 \mu \mathrm{g} / \mathrm{kg}$ would thus be required to provide $\sim 0.5 \mu \mathrm{g} / \mathrm{kg}$ of available melatonin, i.e., an amount equivalent to the nocturnal production rate of melatonin in horse. Melatonin absorption after oral administration occurred rapidly in the present experiment. The time of maximal concentration $(\sim 300 \mathrm{pg} / \mathrm{ml}$ for the $4.0 \mu \mathrm{g} / \mathrm{kg}$ dose) was observed after $30 \mathrm{~min}$. In contrast, a delay of $\sim 3 \mathrm{~h}$ was required after the same dose to return to a mean plasma level of $30 \mathrm{pg} / \mathrm{ml}$, i.e., a concentration equivalent to the calculated mean plasma night concentration. A $4.0 \mu \mathrm{g} / \mathrm{kg}$ melatonin dose by oral route can therefore be assumed to be equivalent to a supplementary night duration of $\sim 3 \mathrm{~h}$ (with respect to an appropriate time of administration) in horse. In 
humans, it was estimated that a melatonin dose from 1.0 to $1.5 \mu \mathrm{g} / \mathrm{kg}$ was enough to raise blood melatonin to nocturnal concentrations (25). This is in agreement with our result, as the oral bioavailability, plasma clearance, and melatonin production rate in humans (13) are of the same order of magnitude as those of the horse.

A final recommendation concerning the dose level to be administered by oral route cannot be made from the present experiment, as bioavailability depends on many factors, including the formulation and horse digestive status. It is not certain that melatonin directly incorporated into food will necessarily be $10 \%$ bioavailable, as with the sugar lump used in the present experiment. The absolute bioavailability after an intragastric administration, which more closely resembles the state of melatonin administration incorporated into food, was only $4 \%$. This suggests that oral administration on a sugar lump results in some perlingual absorption of melatonin, thus avoiding a hepatic first-pass effect. The condition of melatonin administration with respect to food intake itself is probably important too. It has been shown that drug administration before a meal leads to rapid absorption, whereas administration at the end of the meal delays absorption for several hours (14). This is because gastric emptying is only apparent during food intake in horse, and gastric emptying is a prerequisite for the absorption of drugs from the gut.

In conclusion, the present experiment demonstrates that the systemic availability of melatonin after oral administration is very low in the horse and that a pharmacological control of reproductive pattern, based on oral melatonin administration, must be carried out using a dosage regimen at least 10 times higher than the physiological melatonin production rate in this species. A supplementary 3-h pharmacological night can be expected with such a dosage.

Address for reprint requests: P. L. Toutain, Ecole Nationale Vétérinaire de Toulouse, 23 Chemin des Capelles, 31076 Toulouse Cedex, France.

Received 7 December 1993; accepted in final form 17 November 1994.

\section{REFERENCES}

1. Benitez-King, G., J. L. Chavez, L. Huerto-Delgadillo, and A. S. Dic. Characterization of melatonin binding to calmodulin melatonin and the pineal gland. Int. Cong. Endocrinol. IXth Paris, 1992, Abst. no. 15.

2. Berthelot, X., M. Laurentie, J. P. Ravault, J. Ferney, and P. L. Toutain. Circadian profile and production rate of melatonin in the cow. Domest. Anim. Endocrinol. 7: 315-322, 1990.

3. Berthelot, X., J. P. Ravault, D. Concordet, J. Ferney, and P. L. Toutain. Absence of cicardian rhythm in the disposition of melatonin in the cow. J. Pineal Res. 15: 141-146, 1993.

4. Boxenbaum, $\mathbf{H}$. Interspecies variation in liver weight, hepatic blood flow, and antipyrine intrinsic clearance: extrapolation of data to benzodiazepines and phenytoin. J. Pharmacokinet. Biopharm. 8: 165-176, 1980.

5. English, J., C. J. Bojkowski, A. L. Poulton, A. M. Symons, and $J$. Arendt. Metabolism and pharmacokinetics of melatonin in the ewe. J. Pineal Res. 4: 351-358, 1987.

6. Gibbs, F. P., and J. Uriend. The half life of melatonin elimination from rat plasma. Endocrinology 109: 1796-1798, 1981.

7. Gilbaldi, M., and D. Perrier. Pharmacokinetics (2nd ed.). New York: Dekker, 1982.
8. Grubaugh, W., D. C. Sharp, L. A. Berglund, K. J. McDowell, D. M. Kilmer, L. S. Peck, and K. W. Seamans. Effects of pinealectomy in pony mares. J. Reprod. Fertil. Suppl. 32: 293295, 1982.

9. Guillaume, D., and E. Palmer. Effect of oral melatonin on the date of the first ovulation after ovarian inactivity of mares under artificial photoperiod. J. Reprod. Fertil. Suppl. 44: 249-257, 1991.

10. Guillaume, D., and E. Palmer. Light, melatonin and reproduction in the mares. Ann. Zootech. Paris 41: 263-269, 1992.

11. Kilmer, D. M., D. C. Sharp, L. A. Berglund, W. Grubaugh, K. J. McDowell, and L. S. Peck. Melatonin rhythms in pony mares and foals. J. Reprod. Fertil. Suppl. 32: 303-307, 1982.

12. Kopin, J. J., C. M. R. Pare, J. Axelrod, and H. Weissbach. The fate of melatonin in animals. J. Biol. Chem. 226: 3072-3075, 1961.

13. Lane, E. A., and H. B. Moss. Pharmacokinetics of melatonin in man: first pass hepatic metabolism. J. Clin. Endocrinol. Metab. 61: 1214-1216, 1985.

14. Maitho, T. E., P. Lee, and J. B. Taylor. Absorption and pharmacokinetics of phenylbutazone in Welsh mountain ponies. J. Vet. Pharmacol. Ther. 9: 26-39, 1986.

15. Mallo, C., R. Zaidan, G. Galy, E. Vermeulen, J. Brun, G. Chazot, and B. Claustrat. Pharmacokinetics of melatonin in man after intravenous infusion and bolus injection. Eur. J. Clin. Pharmacol. 38: 297-301, 1990.

16. Mo-Yin, C., S. F. Pang, P. L. Tang, and G. M. Brown. Studies on the kinetics of melatonin and $n$-acetylserotonin in the rat at midlight and middark. J. Pineal Res. 1: 227-236, 1984.

17. Ortavant, R., F. Bocquier, J. Pelletier, J. P. Ravault, J. Thimonier, and P. Volland-Nail. Seasonality of reproduction in sheep and its control by photoperiod. Aust. J. Biol. Sci. 41: $69-85,1988$.

18. Palmer, E., M. A. Driancourt, and R. Ortavant. Photoperiodic stimulation of the mare during winter anoestrous. J. Reprod. Fertil. Suppl. 32: 275-282, 1982.

19. Pardridge, W. M., and L. J. Mietus. Transport of albuminbound melatonin through the blood-brain barrier. J. Neurochem. 34: 1761-1763, 1980.

20. Paterson, A. M., C. A. Maxwell, and A. Foldes. Seasonal inhibition of puberty in domestic gilts is overcome by melatonin administered orally, but not by implant. J. Reprod. Fertil. 94: 97-105, 1992.

21. Rollag, M. D., E. S. Panke, W. Trakulrungsi, C. Trakulrungsi, and R. J. Reiter. Quantification of daily melatonin synthesis in the hamster pineal gland. Endocrinology 106: 231$236,1980$.

22. Sharp, D. C., W. Grubaugh, M. T. Zavy, and M. W. Vernon. Seasonal variation in melatonin secretory patterns in mares. $J$. Anim. Sci. 51: 535, 1980.

23. Sharp, D. C., M. W. Vernon, and M. T. Zavy. Alteration of seasonal reproductive patterns in mares following superior cervical ganglionectomy. J. Reprod. Fertil. Suppl. 27: 1-7, 1979.

24. Tillet, Y., J. P. Ravault, C. Selve, G. Evin, B. Castro, and M. P. Dubois. Condition d'utilisation d'anticorps spécifiques pour la visualisation immunohistochimique de la sérotonine et de la mélatonine dans la glande pineale du mouton. C. R. Acad. Ser. III Sci. Vie 303: 77-82, 1986.

25. Vakkuri, O., J. Leppäluoto, and A. Kauppila. Oral administration and distribution of melatonin in human serum, saliva, and urine. Life Sci. 37: 489-495, 1985.

26. Yamaoka, K., T. Nakagawa, and T. Uno. Application of Akaike's information criterion (AIC) in the evaluation of linear pharmacokinetic equation. J. Pharmacokinet. Biopharm. 6: 165$175,1978$.

27. Yamaoka, K., T. Nakagawa, and T. Uno. Statistical moments in pharmacokinetics. J. Pharmacokinet. Biopharm. 6: 547-558, 1978.

28. Yamaoka, K., K. Tanigawara, T. Nakagawa, and T. Uno. A pharmacokinetic analysis program (MULTI) for microcomputer. J. Pharmacobiodyn. 4: 879-885, 1981. 